\title{
Study of changes in soil chemical properties of Asma village of Valsad district
}

L. T. KAPUR, R. F. THAKOR, A. R. PATEL AND K. A. PATEL

Received : 23.04.2016; Revised : 25.04.2016; Accepted : 21.05.2016

MEMBERS OF RESEARCH FORUM:

Corresponding author :

L.T. KAPUR, Krishi Vigyan Kendra, Ambheti, VALSAD (GUJARAT) INDIA

Email: ltkvkambheti@gmail.com;

kvkvalsad@gmail.com
Co-authors :

R. F. THAKOR, A. R. PATEL AND K.A. PATEL, Krishi Vigyan Kendra, Ambheti, VALSAD (GUJARAT) INDIA

\section{Summary}

A study was carried out to examine the changes in soil chemical properties and crop yields in a area of Asma village of Valsad district (Gujarat). The result showed that the mean values of soil $\mathrm{pH}$ and $\mathrm{EC}$ were increased with time. Although, average values of organic carbon, available $\mathrm{P}$ and available $\mathrm{K}$ were decreased year by year. Also difference between maximum and minimum values of soil $\mathrm{pH}, \mathrm{EC}$, organic carbon, available $\mathrm{P}$ and available $\mathrm{K}$ become larger with time due to greatly different in fertilizer application between farmers. Though the yields of crops were increased with cultivation of hybrid varieties but the changes in soil nutrient status have shown there might be need to improve soil management with application of organic and biofertilisers to sustain the fertility of the soil.

Key words : Chemical fertilizers, Soil, Nutrients, Soil health

How to cite this article : Kapur, L.T., Thakor, R.F., Patel, A.R. and Patel, K.A. (2016). Study of changes in soil chemical properties of Asma village of Valsad district. Asian J. Soil Sci., 11 (1) : 222-224 : DOI : 10.15740/HAS/AJSS/11.1/222-224. 